\title{
Penerapan Teknologi Budidaya Ikan Air Tawar Dengan Metode Maxiras dan Aquaponic (Studi Kasus: Kelompok Tani Ikan Desa Kalijaran)
}

\author{
Cahya Vikasari ${ }^{1^{*}}$, Murni Handayani ${ }^{2}$, Oto Prasadi ${ }^{3}$ \\ ${ }^{1}$ Program Studi Teknik Informatika, Polteknik Negeri Cilacap, Indonesia \\ ${ }^{2}$ Program Studi Teknik Mesin Pertanian, Politeknik Negeri Cilacap, Indonesia \\ ${ }^{3}$ Program Studi Teknik Mesin Perikanan, Politeknik Negeri Cilacap, Indonesia \\ Email: ${ }^{1}$ cahyavikasari@ pnc.ac.id, ${ }^{2}$ hanny_seany@yahoo.com, ${ }^{3}$ oto.prasadi@pnc.ac.id
}

\section{INFORMASI ARTIKEL}

\section{Data artikel:}

Naskah masuk, 08 Agustus 2019

Direvisi, 31 Desember 2019

Diterima, 16 Januari 2020
Kata Kunci:

Aquaponic

Maxiras

Budidaya

\begin{abstract}
ABSTRAK
Abstract- Plant cultivation in the village of Kalijaran focuses on rice plants and fish farming with ponds. Some weaknesses of the ground pool are the condition of the soil that is prone to leakage, the ground pool is also difficult to control predatory animals, water discharge as well as water pressure, especially during heavy rain. Community service activities are carried out by applying the method of maxiras, namely carrying out the preparation of tools and materials, installation, training, mentoring and evaluation which are expected to enable more varied plants cultivation and more optimal fishery products, for example using the Ras Maxi method during agricultural activities with the aquaponic method. The purpose of this activity is to be able to create a creative community to cultivate fish and at the same time grow plants using the Maxi Race method. The result of this activity is an increase in the knowledge and skills of fish farmer groups about aquaculture with the Ras Maxi method so that the community can be more economically independent and creative.
\end{abstract}

\begin{abstract}
Abstrak- Budidaya tanaman di desa Kalijaran berfokus pada tanaman padi dan proses budidaya ikan dengan kolam. Beberapa kelemahan dari kolam tanah adalah kondisi tanah yang rentan terhadap terjadinya kebocoran, kolam tanah juga sulit untuk mengendalikan hewan predator, sulit mengendalikan debit air, dan sulit mengendalikan tekanan air terutama saat hujan deras. Kegiatan pengabdian kepada masyarakat dilaksanakan dengan menerapkan metode maxiras yaitu melaksanakan persiapan alat dan bahan, instalasi, pelatihan, pendampingan dan evaluasi yang diharapkan dapat membudidayakan tanaman lebih bervariasi dan hasil perikanan lebih optimal misalnya menggunakan metode Ras Maxi yang dapat ditambahkan ke kegiatan pertanian dengan metode aquaponik. Tujuan dari kegiatan ini adalah dapat menciptakan komunitas kreatif untuk membudidayakan ikan dan pada saat yang sama menanam tanaman dengan menggunakan metode maxi ras. Hasil dari kegiatan ini adalah meningkatnya pengetahuan dan keterampilan kelompok tani ikan tentang
\end{abstract}


akuakultur dengan metode Ras Maxi sehingga membuat masyarakat secara ekonomi lebih mandiri dan kreatif.

\section{Korespondensi:}

\section{Cahya Vikasari}

Program Studi Teknik Informatika, Politeknik Negeri Cilacap

Jl. Dr. Soetomo No.1 Karangcengis, Sidakarya Cilacap, Indonesia

\section{PENDAHULUAN}

Tipologi desa merupakan kondisi secara spesifik keunggulan potensi dari sumber daya alam, sumber daya manusia, potensi kelembagaan serta potensi prasarana serta sarana dalam menentukan arah pengembangan suatu wilayah pedesaan dan kegiatan pembinaan masyarakat desa berdasarkan karakterisrik keunggulan komparatif dan kompetitif dari setiap desa dan kelurahan (Efendi, Bakarudin, \& Rika Despica, 2014). Desa Kalijaran merupakan desa yang berada di wilayah Kabupaten Cilacap. Masyarakat di Desa Kalijaran mayoritas mata pencahariannya adalah sebagai petani dan pembudidaya ikan. Terdapat kelompok tani ikan di Desa Kalijaran dengan nama Pokdakan Mina Jaya, sebanyak 20 orang yang terdaftar pada kelompok tani Pokdakan Mina Jaya dengan luas kolam 7950 $\mathrm{m}^{2}$.

Proses budidaya ikan yang dilakukan oleh Pokdakan Mina Jaya masih menggunakan kolam tanah. Beberapa kelemahan dari kolam tanah yaitu kondisi tanah yang rentan terjadi kebocoran kolam yang diakibatkan oleh hewan perusak seperti kepiting, sulitnya mengontrol hewan predator, adanya kesulitan mengontrol debit air, dan sulitnya mengontrol tekanan air terutama disaat hujan deras. Kegiatan budidaya ikan dan pertanian dilaksanakan dengan ilmu yang didapatkan dari tradisi yang ada didaerah tersebut, penggunaan pupuk non organic bagi tanaman dan libah kotoran ikan yang tidak dimanfaatkan. Masyarakat akan berfokus kepada pertanian saja atau perikanan saja.

Budidaya ikan yaitu proses pembesaran ikan yang dilakukan di Desa Kalijaran yaitu ikan gurami dan ikan lele. Permintaan terhadap kebutuhan ikan sangat tinggi di masyarakat baik untuk konsumsi rumah tangga atau untuk usaha. Ikan merupakan makanan sumber protein hewani selain daging hewan ternak darat, telur dan susu serta merupakan salah satu jenis makanan yang memenuhi kriteria gizi berimbang (Wibowo, Darmanto, \& Amalia, 2015). Budidaya ikan lele di Desa Kalijaran memerlukan waktu yang lebih cepat sekitar 3,5 bulan dibandingkan dengan budidaya ikan gurami sekitar 11 bulan. Kurangnya keterampilan atau pengetahuan mengenai pembudidayaan ikan salah satu penyebab kurangya produksi selain itu juga faktor alam ikut mempengaruhi produksi hasil perikanan. Akan tetapi, yang lebih utama adalah harga pasar terhadap hasil panen ikan yang akan memberi semangat para pembudidaya ikan dan sumber daya manusia yang mengelola budidaya ikan serta pakan yang didatangkan dari luar daerah yang sangat mahal akan mempengaruhi ketertarikan dalam pembudidayaan ikan.

Masyarakat Desa Kalijaran masih menggunakan teknik dengan menggunakan kolam tanah sehingga yang memerlukan lahan yang luas dan tebar benihnya tidak terlalu padat. Gagal panen hasil perikanan merupakan hal yang paling ditakuti oleh masyarakat sebelum mereka mau bergerak dan mencoba kegiatan pembudidayaan ikan air tawar dengan metode yang lain. Budidaya ikan yang dilakukan secara manual akan memunculkan resiko kegagalan panen serta akan membuat rugi petani ikan sehingga pada akhirnya akan membuat semangat petani ikan menurun karena kegagalan panen tersebut dan kolam ikan tidak diberdayakan kembali.

Berdasarkan beberapa permasalahan yang dipaparkan di atas, maka perlu diadakan pemberdayaan masyarakat di bidang perikanan dan pertanian yaitu dengan melaksanakan kegiatan budidaya ikan yang dapat ditambahkan dengan kegiatan pertanian atau bercocok tanam dengan sistem aquaponic. Pemberdayaan masyarakat merupakan upaya dalam memulihkan serta meningkatkan keberdayaan komunitas atau kelompok masyarakat agar mampu berbuat sesuai dengan 
harkat dan martabat mereka dalam melaksanakan hak serta tanggung jawab sebagai komunitas manusia dan warga negara. Salah satu kegiatan program kemitraan masyarakat dilakukan adalah di Desa Kalijaran untuk kelompok Tani Ikan Pokdakan Mina Jaya dengan menerapkan teknologi budidaya ikan air tawar dengan metode maxiras dan aquaponics.

Permintaan masyarakat terhadap produk perikanan semakin meningkat pertumbuhan jumlah penduduk di Indonesia serta adanya kesadaran untuk hidup sehat (Yulandari Y, Tjahjono, \& Riniwati, 2015). Pendampingan terhadap masyarakat didesa Kalijaran perlu dilakukan untuk menambah pengetahuan dan keterampilan masyarakat dalam teknologi untuk membudidayakan ikan dengan metode maxi ras yang akan mengadopsi sistem aliran air di sungai serta menambahkan metode untuk memproduksi tanaman yang dapat dikolaborasikan dengan budidaya ikan yaitu budidaya tanaman dengan konsep aquaponic.

Teknologi RAS adalah salah satu teknologi yang banyak dipakai dalam kegiatan budidaya perikanan yang dilaksanakan secara intensif dalam beberapa tahun ini. Pengembangan teknologi RAS dalam budidaya berbagai jenis ikan banyak dilakukan salah satunya oleh Negara Norwegia selama kurun waktu 20-30 tahun (Thesiana \& Pamungkas, 2015). Resirkulasi akuakultur ini merupakan teknologi yang digunakan pada budidaya perikanan maupun organisme perairan dengan cara memanfaatkan kembali air yang telah digunakan dalam sistem produksi atau air bekas. Sistem ini menggunakan filter mekanik dan biologis pada wadah terkontrol dan bisa digunakan untuk budidaya ikan (Lele BioMaksi, 2017).

Resirkulasi aquakultur ini akan dimanfaatkan untuk sirkulasi air pada tanaman aquaponik yang akan mengalirkan air dalam kolam ikan yang mengandung sisa pakan dan kotoran ikan yang akan menutrisi tanaman tersebut. Resirkulasi atau perputaran air dalam kegiatan budidaya ikan berfungsi dalam membantu keseimbangan biologis di dalam air, membantu dalam distribusi oksigen, menjaga kestabilan suhu dalam kolam serta menjaga akumulasi yaitu mengumpulkan hasil metabolit beracunyaitu dari limbah kotoran ikan sehingga kadar racun dapat ditekan(Mulyadi, Usman Tang, 2014).

Sistem aquaponik mengoptimalkan penyediaan air untuk masing-masing komoditas yaitu tanaman dan ikan. Penggabungan metode maxi ras untuk budidaya ikan dan aquaponic untuk budidaya tanaman dapat menjamin kadar oksigen air serta menekan zat amonia yang dihasilkan oleh ikan lele karena amonia ini akan menjadi nutrisi oleh tanaman. Sistem aquaponik dapat dimanfaatkan oleh skala rumah tangga dan jika dalam skala besar dapat digunakan untuk komersil dan membidik pasar hasil tanaman organik karena masyarakan akan lebih menghargai hasil tanaman organik dengan nilai jual yang lebih tinggi. Sistem ini akan akan mengurangi penggunaan dari air karena akan terjadi sirkulasi yang akan menjamin ketersediaan air dalam sistem budidaya ikan dan tanaman. Sistem ini juga akan menambah hasil produksi ikan dengan padat tebar benih dan sistem ini akan membuat daya tahan hidup ikan lebih tinggi sehingga akan berpengaruh pada hasil panennya, juga akan mendapat nilai tambah dari hasil tanaman yang dihasilkan. Lahan yang dibutuhkan untuk sistem ini lebih sedikit dibanding dengan kolam tanah sehingga masyarakat yang mempunyai lahan yang sempit juga dapat menerapkan metode ini. Dengan kemudahan dari metode maxi ras dan aquaponic ini serta hasil yang didapat maka akan membuat para petani untuk mencoba menerapkan metode ini untuk produksi ikan dan tanaman.

Target dan luaran dari kegiatan program kemitraan masyarakat ini yaitu kelompok tani ikan Pokdakan Mina Jaya Desa Kalijaran menjadi faham atau bertambah pengetahuan dan terampil dalam membudidaya ikan sekaligus bercocok tanam dengan teknologi maxiras dan aquaponic.

\section{METODE PELAKSANAAN}

Metode pelaksanaan kegiatan program kemitraan masyarakat dengan mitra kelompok tani ikan Pokdakan Mina Jaya Desa Kalijaran dilakukan melalui pelatihan budidaya ikan lele dengan teknik maxiras dan aquaponic serta dilakukan pendampingan. Pelatihan dilakukan 
baik melalui materi budidaya ikan lele menggunakan metode maxiras serta pemanfaatan limbah ikan lele untuk kegiatan bercocok tanam dengan menggunakan sistem aquaponic berupa ceramah dan diskusi, pelatihan dan pendampingan ke kolam dengan demonstrasi cara budidaya ikan lele dengan metode maxiras dan aquaponic.

Kegiatan pendampingan pada kelompok tani ikan Pokdakan Mina Jaya Desa Kalijaran dilakukan setelah tahap awal yaitu tahap pelatihan. Pendampingan dilakukan dari awal pemeliharaan benih ikan lele sampai tahap pemanenan ikan dan tanaman. Proses pelatihan dan pendampingan budidaya ikan lele dengan metode maxiras dan aquaponic ini dilakukan kepada kelompok tani Pokdakan Mina Jaya Desa Kalijaran. Kegiatan dilaksanakan setelah dilakukan persiapan yang berupa tahap persiapan alat, instalasi peralatan untuk budidaya ikan dan tanaman. Tahapan kegiatan pelaksanaan program kemitraan masyarakat dapat dilihat pada Gambar 1.

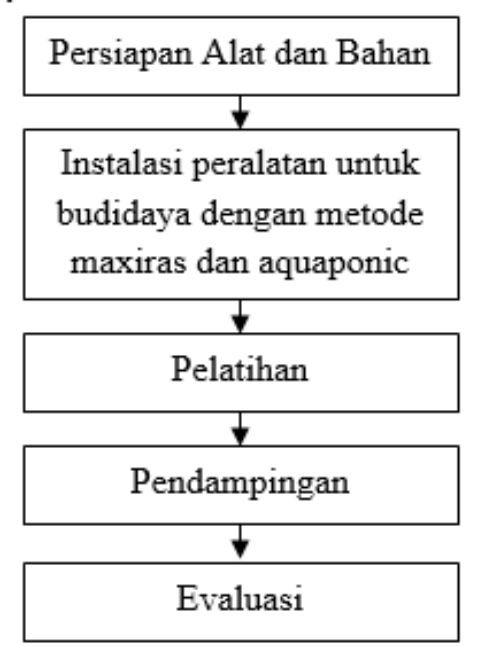

Gambar 1. Tahapan Kegaitan Pelaksanaan PKM

Tahap awal yaitu persiapan alat dan bahan yang diperlukan dalam kegiatan implementasi budidaya ikan dengan metode maxiras. Persiapan rak hidroponik dan rangkaian hidroponik untuk menanam tanaman yang dapat memanfaatkan timbah dari kotoran ikan dan dilanjutkan dengan instalasi kolam terpal dan melakukan instalasi pipa sesuai dengan metode maxiras dan aquaponik. Transfer ilmu dari tim kepada kelompok tani dapat dilakukan pada saat pembuatan rangkaian kolam ikan dengan metode maxi ras.
Pelatihan dilaksanakan setelah persiapan dan instalasi telah selesai dilaksanakan. Pelatihan dilakukan dengan target peserta yaitu anggota kelompok tani ikan pokdakan minajaya. Pendampingan juga dilaksanakan untuk memastikan kelompok tani pokdakan minajaya dapat mengaplikasikan pengetahuan dan keterampilan mengenai metode yang telah diajarkan. Evaluasi terhadap pelaksanaan dan pelatihan sebagai dasar untuk mengetahui tingkatan pengetahuan dan keterampilan dari kelompok tani ikan serta sebagai evaluasi untuk pengembangan metode yang dapat dikembangkan.

\section{HASIL DAN PEMBAHASAN}

Kegiatan program kemitraan masyarakat telah sampai kepada tahap pelaksanaan pelatihan dan pendampingan. Kegiatan dilaksanakan pada hari Jumat, 2 Agustus 2019. Peserta kegiatan adalah kelompok tani ikan Pokdakan Mina Jaya Desa Kalijaran dan hadir pula mahasiswa KKN Universitas Jenderal Soedirman dan mahasiswa teknik mesin Pertanian Politeknik Negeri Cilacap. Kegiatan dilaksanakan dengan mmberikan arahan mengenai metode maxi ras kepada peserta, kemudian peserta melakukan praktek untuk menanam dengan konsep hidroponik yang dapat diterapkan pada budidaya ikan dengan maxi ras. Kegiatan lain yaitu peserta melihat secara langsung kolam dan rangkaian hidroponik yang sudah tim buat sebagai sarana pembelajaran secara langsung mengenai metode maxi ras.

Peserta sangat antusias mengikuti serangkaian proses kegiatan program kemitraan masyarakat. Hasil kegiatan program kemitraan masyarakat adalah kelompok tani ikan Pokdakan Mina Jaya menjadi faham dan terampil dalam kegiatan pembudidayaan ikan dengan teknologi yang telah diterapkan yaitu metode maxiras dan aquaponic. Dengan adanya kegiatan program kemitraan masyarakat khususnya kelompok tani ikan Pokdakan Mina Jaya selain mendapat hasil berupa ikan juga mampu mengelola limbah budidaya ikan lele untuk menghasilkan suatu produk yaitu tanaman dengan sistem aquaponic.

Persiapan alat dan bahan yang diperlukan dalam kegiatan implementasi budidaya ikan dengan metode maxiras yaitu mempersiapkan rak hidroponik dan rangkaian hidroponik. 
Persiapan bahan kegiatan dapat dilihat pada Gambar 2.

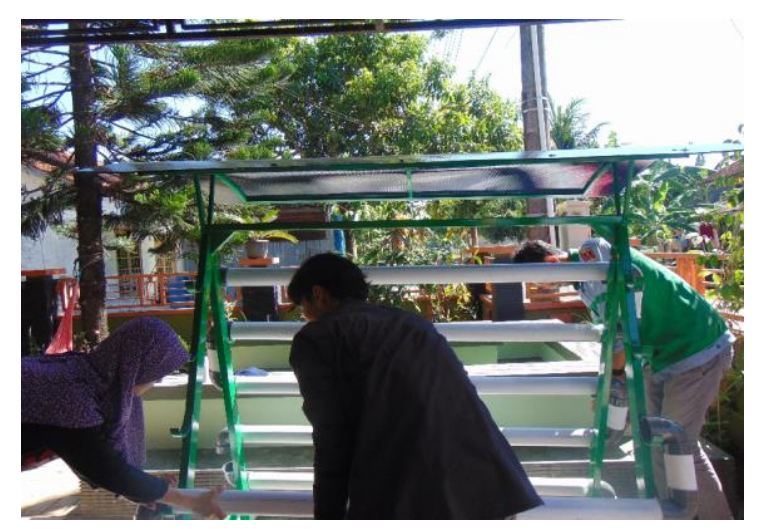

Gambar 2. Persiapan Bahan Dan Alat Kegiatan

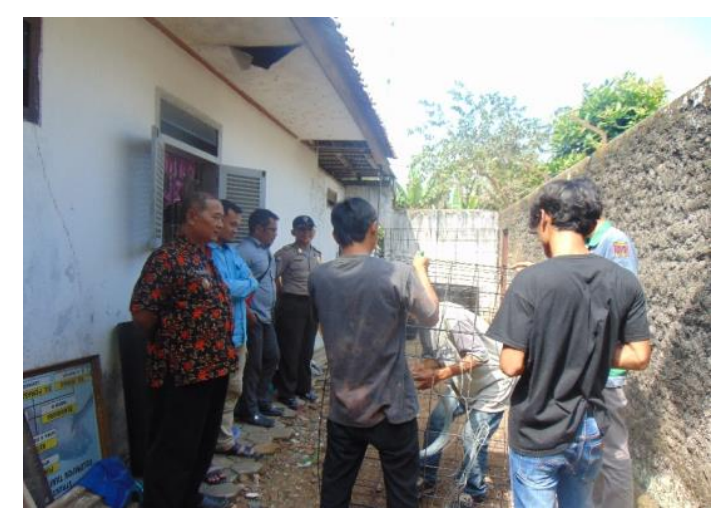

Gambar 3. Pembuatan kolam terpal

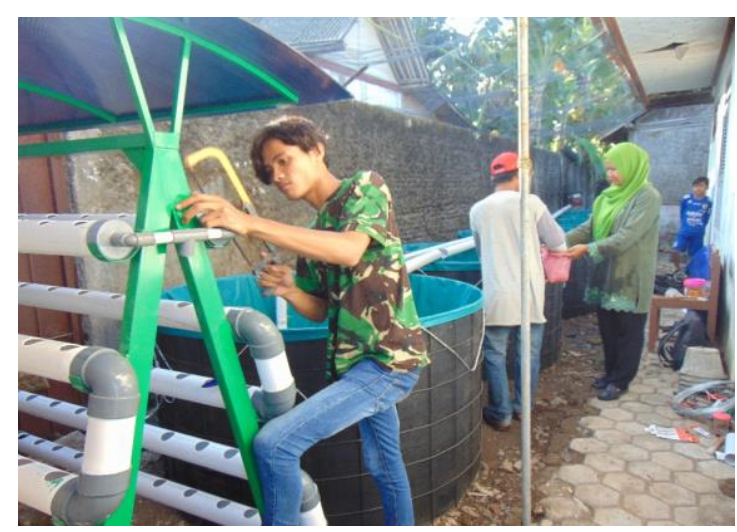

Gambar 4. Persiapan Kolam Dengan Metode Maxiras

Instalasi kolam terpal dan melakukan instalasi pipa sesuai dengan metode maxiras dan aquaponik. Transfer ilmu dari tim kepada kelompok tani dapat dilakukan pada saat pembuatan rangkaian kolam ikan dengan metode maxi ras. Instalasi kolam terpal dapat dilihat pada Gambar 3. Hasil dari kegiatan instalasi kolam dan rangkaian hidroponik dilanjutkan pengisian air dalam kolam agar siap untuk proses selanjutnya yaitu penebaran bibit ikan lele pada kolam terpal berikut kegiatan persiapan implementasi kolam ikan dengan metode maxiras dapat dilihat pada Gambar 4.

Selain pembangunan kolam juga akan dilakukan teknik penanaman tanaman dengan memanfaatkan kolam ikan dengan konsep aquaponik. Teknologi akuaponik adalah metode teknologi yang mengkombinasikan akuakultur dan hidroponik yang mempunyai tujuan untuk memelihara ikan serta bercocok tanam dalam satu sistem yang saling terhubung (Sibarani, 2013). Limbah atau kotoran yang dihasilkan oleh ikan seperti feses dan pakan, digunakan kembali sebagai pupuk untuk tanaman dengan konsep aquaponik. Kemudian air yang dialirkan dari kolam ikan atau media pemeliharaan ikan dibersihkan olah tanaman sehingga dapat digunakan kembali oleh ikan (Estim, Yong, Kian, \& Senoo, 2010). Menurut Rokocy (Masser \& Losordo, 2016) interaksi antara budidaya ikan dan tanaman yang dibudidayakan menghasilkan lingkungan yang sangat ideal untuk pertumbuhan sehingga lebih produktif dari metode tradisional.

Tabel kegiatan program kemitraan masyarakat di pokdakan minajaya dapat dilihat pada Gambar 5. Kegiatan program kemitraan masyarakat ini yang telah dilaksanakan dengan tahapan persiapan, instalasi peralatan, pelatihan, pendampingan dan evaluasi pada kelompok tani ikan pokdakan minajaya dapat menambah pengetahuan dan keterampilan masyarakat dalam menerapkan teknologi untuk membudidayakan ikan dengan metode maxiras yang mengadopsi sistem aliran air sungai serta menambahkan metode untuk memproduksi tanaman dengan sistem aquaponic. 


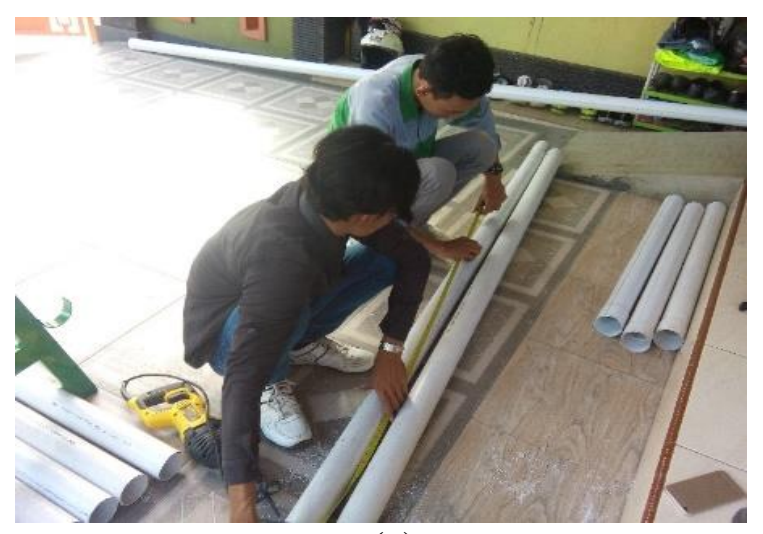

(a)

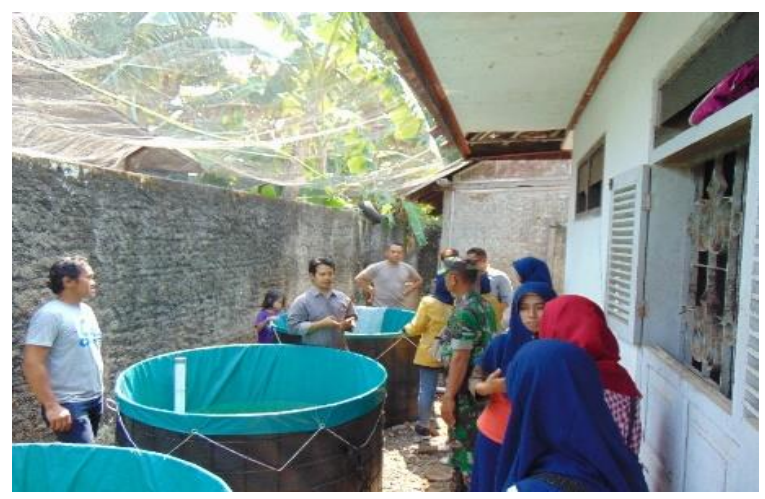

(c)

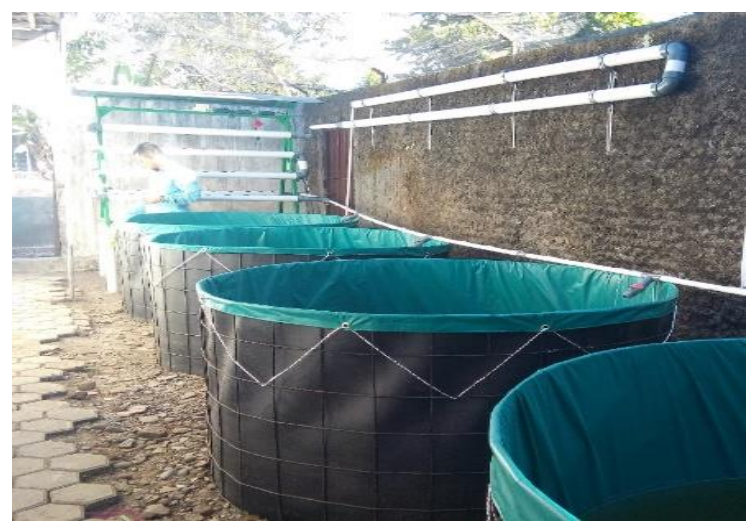

(f)

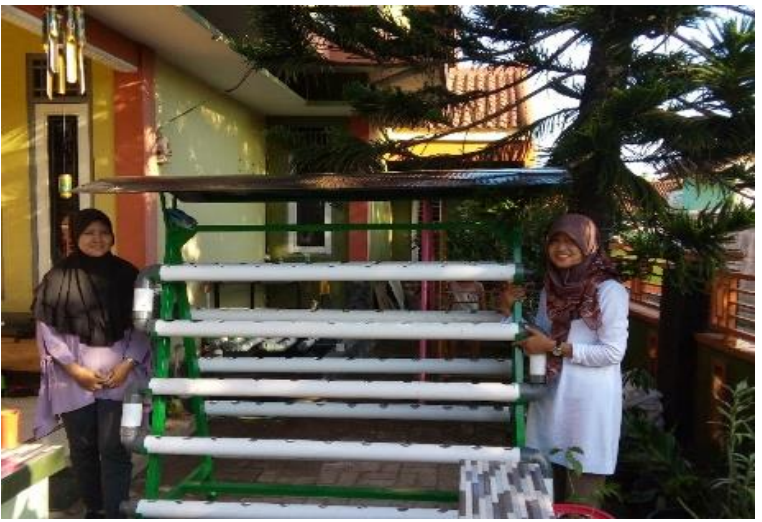

(b)

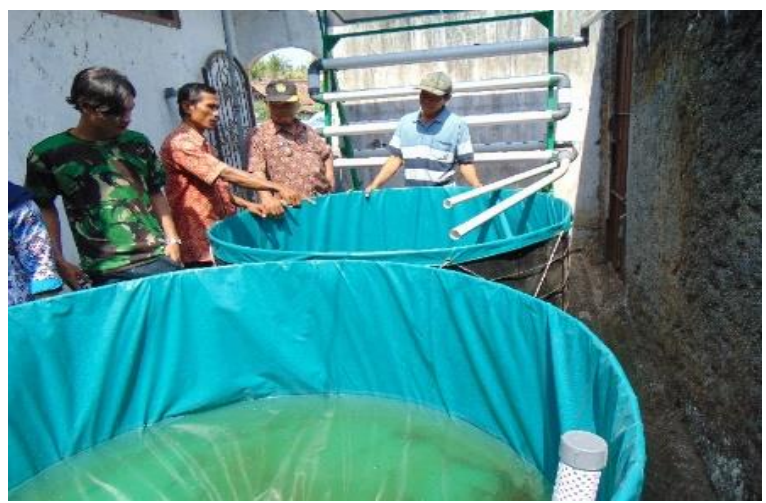

(d)

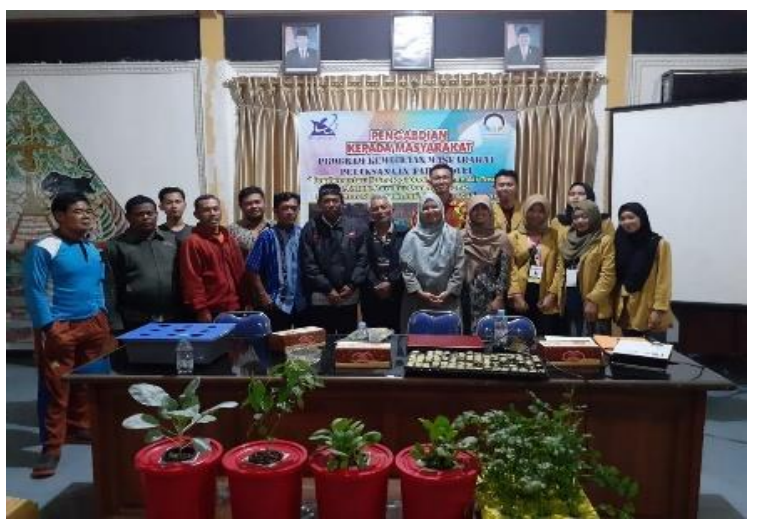

(g)

Gambar 5. (a) Kegiatan persiapan untuk pipa sistem aquaponics; (b) Rak untuk sistem aquaponics; (c) Penjelasan tentang metode maxiras dan aquaponics; (d) Kegiatan pengisian air untuk budidaya ikan; (f) Hasil instalasi kolam dan pipa aquaponics; (g) Kegiatan sosialisasi dan pelatihan

Penggunaan metode ini akan memanfaatkan resirkulasi air limbah kotoran ikan menjadi pupuk alami bagi tanaman. Kemudahan dalam mengontrol hewan predator, mengontrol debit air dengan menggunakan metode maxiras dalam budidaya ikan dan tanaman.

\section{KESIMPULAN}

Kesimpulan yang dapat diambil dari kegiatan program kemitraan masyarakat ini yaitu bahwa kegiatan yang dilaksanakan dapat menambah pengetahuan dan keterampilan masyarakat khususnya kelompok tani ikan Pokdakan Mina Jaya dalam menerapkan 
teknologi untuk membudidayakan ikan dengan metode maxiras yang mengadopsi sistem aliran air sungai serta menambahkan metode untuk memproduksi tanaman dengan sistem aquaponic. Selain itu, dapat mempermudah control terhadap hewan predator dan control debit air dalam budidaya ikan dan tanaman.

Saran dalam kegiatan program kemitraan masyarakat yaitu perlu adanya budaya untuk mengubah cara budidaya ikan dan pertanian dengan teknologi yang lebih menguntungkan misalnya dengan maxiras.

\section{UCAPAN TERIMA KASIH}

Ucapan terimakasih kami sampaikan kepada DRPM Kemenristekdikti dalam pendanaan kegiatan kemitraan masyarakat, Politeknik Negeri Cilacap, Kepala P3M Politeknik Negeri cilacap yang telah memberi dukungan dalam pelaksanaan kegiatan program kemitraan masyarakat, Kelompok tani pokdakan minajaya dan semua pihak yang telah membantu kegiatan program kemitraan masyarakat ini.

\section{DAFTAR PUSTAKA}

Efendi, S., Bakarudin, \& Rika Despica. (2014). Tipologi Desa Berdasarkan Mata Pencaharian Penduduk di Kecamatan Koto Kabupaten Mukomuko. PGRI PADANG SUMATERA BARAT.

Estim, A., Yong, A., Kian, S., \& Senoo, S. (2010). Producing Organic Fish and Mint in an Aquaponic System A Model of Green Technology in Action. Aquaponic Juournal.

Harahap, E. F. (2012). Pemberdayaan Masyarakat Dalam Bidang Ekonomi Untuk Mewujudkan Ekonomi Nasional
Yang Tangguh Dan Mandiri. Manajemen Dan Kewirausahaan, 3(1), 78-96.

Lele BioMaksi. (2017). Maxi Ras. Retrieved August 10, 2018, from http://www.lelebiomaksi.com/maxi-ras/

Masser, M. P., \& Losordo, T. (2016). Recirculating Aquaculture Tank Production Systems: Aquaponics Integrating Fish and. SRAC Publication, (January 2006).

Mulyadi, Usman Tang, E. S. Y. (2014). Lecturers of Fisheries and Marine Science Faculty Riau University Student of Fisheries and Marine Science Faculty Riau University. Jurnal Akuakultur Rawa Indonesia, 2(2), 117-124.

Sibarani, O. A. (2013). Pengaruh Pemberian Em4 Pada Media Biofilter Terhadap Kelangsungan Hidup Dan Laju Pertumbuhan Ikan Nilem (Osteochilus Hasselti) Dengan Sistem Akuaponik. Universitas Padjajaran.

Thesiana, L., \& Pamungkas, A. (2015). Uji Performansi Teknologi Recirculating Aquaculture System (Ras) Terhadap Kondisi Kualitas Air Pada Pendederan Lobster Pasir Panulirus Homarus. Jurnal Kelautan Nasional, 10(2), 65. https://doi.org/10.15578/jkn.v10i2.6158

Wibowo, T. A., Darmanto, Y. S., \& Amalia, U. (2015). Karakteristik Kekian Berbahan Baku Surimi Ikan Kurisi (Nemipterus Nematophorus) Dengan Penambahan Daging Ikan Yang Berbeda. Jurnal Pengolahan Dan Bioteknologi Hasil Perikanan, 4(2008), 1-10.

Yulandari Y, L., Tjahjono, A., \& Riniwati, H. (2015). Perencanaan Pengembangan Bisnis Pengolahan Ikan Pada Rumah Makan Mina Sari Tlogomas, Malang, Jawa Timur. Jurnal Ecsofim, 3(1). 